\title{
Penggunaan Media Massa untuk Mengedukasi Masyarakat Tentang Pemasyarakatan
}

\author{
Miftahus Surur Ramadhan \\ Politeknik IImu Pemasyarakatan \\ ramadhanmiftahus@gmail.com
}

DOI: $10.23917 / / a j . v 5 i 1.10421$

Submission
Track:
Received:
01 Maret 2020
Final Revision:
19 Maret 2020
Available online:
28 April 2020
Corresponding
Author:
Miftahus Surur
Ramadhan
ramadhanmiftahus@
gmail.com

Submission ABSTRAK

Tujuan dari penelitian ini untuk menganalisis tingkat keperdulian masyarakat tentang hak asasi tahanan dan narapidana, serta memberikan solusi yang dapat dilakukan oleh pemerintah untuk mengedukasi masyarakat tentang sistem pemasyarakatan agar masyarakat mengubah pandangan buruk dan meningkatkan keperduliannya terhadap hak asasi tahanan dan mantan narapidana. Metodologi yang digunakan oleh penulis adalah metode kualitatif. Penulis memperoleh data dengan menggunakan metode pengambilan data primer berupa wawancara dan data sekunder. Untuk teknik analisa data yang digunakan oleh penulis adalah (1) reduksi data, (2) data display (paparan data), dan (3) penarikan kesimpulan. Hasil penelitian menunjukkan bahwa masih banyak masyarakat yang memandang buruk tahanan dan mantan narapidana, padahal tahanan dan narapidana juga manusia yang memiliki hak asasi manusia yang harus dijunjung tinggi dan diayomi oleh masyarakat termasuk pemerintah. Maka pemerintah wajib berperan dalam mengedukasi masyarakat tentang sistem pemasyarakatan agar masyarakat mengerti bahwa tahanan dan narapidana itu tidak selamanya buruk. Kegunaan dari tulisan ini adalah untuk memberikan saranpada pemerintah dan meningkatkan keperdulian masyarakat terhadap hak-hak asasi dari tahanan dan mantan narapidana, agar masyarakat tidak lagi selalu berpandangan buruk terhadap tersangka dan terdakwa, dan mantan narapidana yang sudah kembali kedalam masyarakat dapat hidup seperti manusia normal kembali. Dalam penelitian ini menunjukkan bahwa peran pemerintah dalam mengedukasi masyarakat tentang pemasyarakatan dan nilai-nilai hak asasi tahanan narapidana masih belum optimal, karena pemerintah hanya baru mensosialisasikannya dengan cara konvensional. Hal yang dapat dilakukan pemerintah adalah menggunakan media massa untuk menyebarkan iklan dan pesan singkat, dengan meniru gaya promosi pembisnis.

Kata kunci: Media massa, Edukasi, Pemasyarakatan, Hak asasi manusia. 


\begin{abstract}
This study aims to analyze the level of awareness of society about the rights of prisoners and inmates, as well as provide a solution that can be done by the government to educate the public about the system of correctional that people change the view of the bad and increase their care against the rights of human prisoners and ex-convicts. The methodology that is used by a writer is method qualitative. The author obtained the data by using the method of collection of primary data in the form of interviews and the data secondary. Data analysis techniques used by the author are (1) data reduction, (2) data display,, and (3) concluding. The results of the study show that still many people who look lousy prisoner and ex-convictt, even though prisoners also human beings who have a right to the basic human who must be upheld high and be acknowledged by the community including the Government. Then the Government shall educate the public about the system of penitentiary so that people understand that prisoners are not always bad. The usefulness of writing this is advising Government and increase the care of society to rights of prisoners so that people no longer ever think bad or suspects and defendants. The former speaker was already back into community and have a life like a normal person. In research, this shows that the Government in educating the public about correctional and values of rights of prisoners still not optimal because the Government is only just socialized with the way conventional. Things that the Government can do is using the media mass to disseminate advertising by imitating the style of promotion business.
\end{abstract}

Keywords: Mass media, Education, Correctional, Human rights.

\title{
PENDAHULUAN
}

Lembaga pemasyarakatan di Indonesia masih menjadi perhatian publik dari masyarakat, karena banyaknya permasalahan yang terjadi. Mulai dari over kapasitas, residivis, disorientasi seks, dan masih banyak lagi. hal ini menjadi tamparan bagi pemerintah untuk segera menyelesaikan permasalahan-permasalahan ini. Hak Asasi Manusia adalah hak yang dari lahir sudah melekat pada setiap individu manusia (termasuk tahanan dan narapidana. Didalam undang-undang no.39 tahun 1999 tentang Hak Asasi Manusia dijelaskan juga bahwa setiap orang berhak untuk mengembangkan diri, memperoleh keadilan, hak atas rasa aman yang sama termasuk juga tahanan dan mantan narapidana yang berhak untuk memperoleh keadilan, rasa aman, dan hak untuk mengembangkan diri. Dalam beberapa tahun belakangan ini banyak terjadi kasus yang khusus, seperti :

1. Nenek 92 tahun yang dihukum 1 bulan penjara karena menebang pohon durian milik kerabatnya.

2. Nenek yang dihukum 1 tahun penjara karena mencuri kayu. 
3. Nenek yang mengambil 3 buah kakao yang dipenjara (Akmala, 2020)

4. Dan beberapa kasus lainnya. (Brilio, 2018)

Hal ini terjadi karena masih banyak masyarakat luar yang masih belum memahami dan belum mengerti tentang sistem pemasyarakatan, yang menyebabkan kurang perhatiannya masyarakat terhadap nilai-nilai HAM tahanan dan narapidana. Dan juga kebanyakan masyarakat berfikir buruk bahwa tahanan yang statusnya sebagai tersangka harus diberikan hukuman penjara. dan juga narapidana yang telah menjalani proses pembinaan didalam lapas, setelah keluar dan kembali kekehidupannya dimasyarakat, malah mendapatkan citra buruk yang membuat mantan narapidana tersebut tidak bisa hidup kembali seperti orang normal pada umumnya sebelum dia masuk kedalam lapas. Hal ini juga terjadi karena kebanyakan masyarakat masih menggunakan paradigma lama yaitu paradigma penjara. Padahal sejak 1945 undang diperlakuan terhadap narapidana mendapat perhatian khusus dari kalangan dunia internasional karena perlakuan tersebut berlandaskan pada perikemanusiaan hingga terciptanya "Standart Minimum Rules for the Treatment of Prisoners" (SMR). (Messaile, 2015)

Menurut Satjipto Rahardjo, Perlindungan hukum adalah memberikan pengayoman terhadap hak asasi manusia (HAM) yang dirugikan orang lain dan perlindungan itu diberikan kepada masyarakat agar menikmati semua hak-hak yang diberikan oleh hukum. Apabila dikaitkan dengan teori tersebut, maka semua orang (termasuk pemerintah dan masyarakat) wajib memberikan pengayoman kepada hak asasi manusia tahanan dan mantan narapidana, agar tahanan dan mantan narapidana tersebut dapat merasakan semua hak-hak yang diberikan oleh hukum. (Nola, 2016)

Permasalahan yang terjadi pada saat ini ialah adanya perbedaan pandangan antara masyarakat dan aparat penegak hukum (APGAKUM), dengan petugas pemasyarakatan itu sendiri terkait citra tahanan dan narapidana yang mngakibatkan stigma dan pendapat buruk masyarakat terhadap tahanan yang statusnya masih sebagai tersangka yang sedang menjalani proses pengadilan dan narapidana yang sudah selesai menjalani masa pidananya. (Victorio H.Situmorang, 2019) Adapun rumusan masalah dari latar belakang tersebut adalah bagaimana cara untuk meningkatkan keperdulian masyarakat terhadap hak asasi tahanan dan mantan narapidana dengan menggunakan media massa. 


\section{METODE PENELITIAN}

Pendekatan yang digunakan oleh peneliti dalam penelitian ini adalah metode penelitian kualitatif. Menurut Creswell (2010: 4), penelitian kualitatif merupakan metode-metode untuk mengeksplorasi dan memahami makna yang oleh sejumlah individu atau sekelompok orang dianggap berasal dari masalah sosial atau kemanusiaan. Sumber data yang penulis ambil adalah dengan cara pengumpulan informasi dan data melalui pemeriksaan dan analisis informasi, dan data menggunakan data primer dan data sekunder. Menurut (Uma sekaran, 2011) data primer meupakan data yang mengacu pada informasi yang diperoleh dari tangan pertama oleh peneliti yang berkaitan dengan variable minat untuk tujuan spesifik studi. Sumber data primer adalah responden individu, kelompok focus, internet (apabila kuisioner disebar menggunakan internet). Sedangkan data sekunder (Uma sekaran, 2011) merupakan data yang mengacu pada informasi yang dikumpulkan dari sumber yang telah ada. Sumber data sekunder adalah catatan web, internet, dan sebagainya.Yang menjadi sumber data primer dalam penelitian ini adalah hasil wawancara. Menurut Sedangkan yang menjadi sumer data sekunder adalah literatur, artikel, jurnal, serta laman internet yang berkaitan dengan penelitian yang dilakukan. Untuk teknik analisa data yang digunakan oleh penulis adalah (1) reduksi data, (2) data display (paparan data), dan (3) penarikan kesimpulan. (Bachri, 2010)

\section{HASIL DAN PEMBAHASAN}

\section{A. Media massa}

Media massa adalah salah satu alat dalam proses komunikasi masyarakat. Media massa mampu menyebarluaskan informasi yang lebih luas kekhalayak orang. Ddalam kajian komunikasi, media massa sering dipahami sebagai perangkat yang dikelompokkan untuk berkomunikasi secara terbuka dan sifatnya terbuka untuk khalayak orang dalam waktu yang singkat. Menurut bungin, media massa adalah alat komunikasi untuk menyebarkan informasi secara massa dan dapat diterima oleh masyarakat luas. (Santosa, 2017)

Sekarang ini baik dunia dan termasuk negara Indonesia mengalami revolusi industry, yang mana revolusi industry kini sudah mencapai tahap keempat, atau biasa disebut dengan revolusi industi 4.0 .fase pertama (1.0) adalah penemuan mesin yang menitikberatkan bada mekanisasi produksi. Fase kedua (2.0) sudah beranjak pada etape produksi massal yang terintegrasi dengan quality control dan standarisasi. fase ketiga (3.0) memasuki tahapan komputerisasi. Fase keempat (4.0) adalah masa kini, yang mana pada fase keempat ini telah 
menghadirkan era digitalisasi dan internet. hal yang melatarbelakangi terjadinya revolusi industry ini adalah tujuan untuk memenuhi kebutuhan manusia, agar segala sesuatunya menjadi efektif dan efisian dalam hal mengerjakannya. (Ghufron, 2018) Istilah "Revolusi Industri" pertama diperkenalkan oleh Friedrich Engels dan Louis-Auguste Blanqui dipertengahan abad ke-19. (Suwardana, 2018) Salah satu contoh nyata dari revolusi industry 4.0 adalah penggunaan sosial media. Menurut Philip Kotler dan Kevin lane keller (2016), media social adalah media yang digunakan oleh konsumen untuk berbagi teks, gambar suara, dan video informasi baik dengan orang lain maupun perusahaan dan vice versa.

Jenis-jenis media massa data diklasifikasikan menjadi 3 jenis, yaitu :

a. Media cetak

Media massa ada tahun 1920-an diakai oleh emerintah untuk mendoktrin masyarakat, sehingga membuat masyarakat membaca dan menerapkan seseuatu tujuan dari apa yang diinginkan oleh pemerintah. Media cetak ini dapat dicontohkan seerti majalah, buku, artikel, tulisan-tulisan yang dibuat untuk masyarakat luas.

b. Media elektronik

Setelah hadirnya media cetak yang dibuat oleh pemerintah kepada masyarakat untuk suatu tujuan tertentu, hadirlah media elektronik yang menyampaikan pesan kepada orang lain dengan suara. Media elektronik pertama ini biasa disebut dengan radio, yang hingga saat ini masih sering digunakan oleh masyarakat banyak. Kelebihan dari radio ini adalah data menyampaikan pesan suara secara langsung dan cepat. Dan erlu diketahui juga, bahwa pada saat pembacan teks proklamasi kemerdekaan Negara Republik Indonesia (NKRI), pada saat itu alat yang digunakan adalah radio ini sebagai media massa yang berperan penting dalam penyebaran informasi.

c. Media internet

Media internet ini mulai populer pada saat abad ke-21, pada saat itu media internet pertama yang dikenalkan kedunia adalah hasil temuan dari Larry page dan Sergey Brin yaitu google sebagai media informasi internet pertama. Dengan misi dari google tersebut adalah "mengumpulkan informasi dunia dan membuatnya dapat diakses dan bermanfaat oleh semua orang." Perlu diketahui juga bahwa media cetak dan media elektronik dapat dimasukkan kedalam media internet dengan melalui website. Contoh dari media internet lainnya selain google adalah uc.browser, opera, dll. (Muslich, n.d.) 
Seiring dengan perkembangan zaman, teknologi sebagai media komunikasi pun ikut berkembang. Mungkin dulu manusia mengirim dan mendapatkan informasi hanya melalui saluran radio, televise, dan koran. Akan tetapi, karena akal manusia yang selalu mencari solusi untuk kebutuhan manusia, khususnya dibidang komunikasi, hadirlah social media seperti Instagram, whatsapp, dll. (Husaini dan Lampung, 2014)

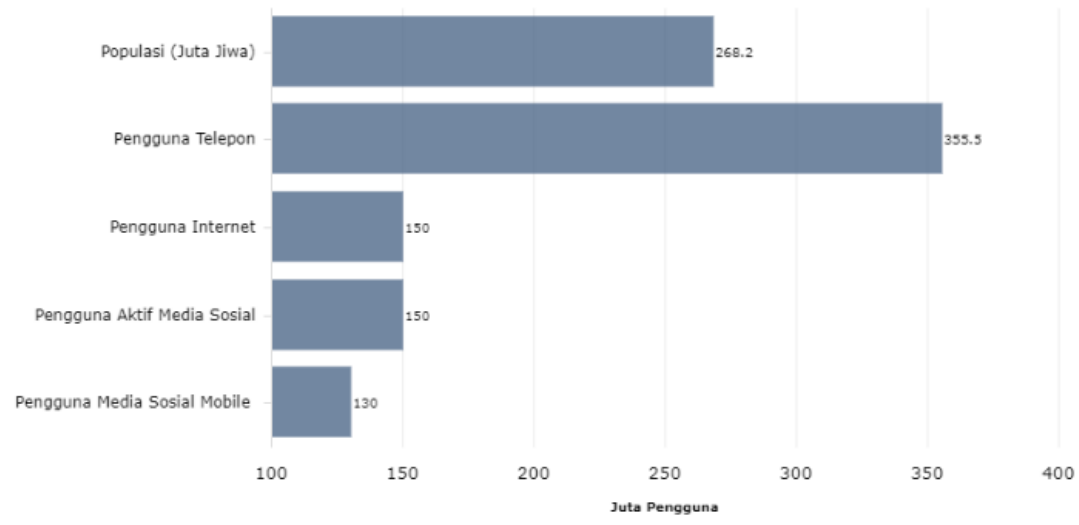

Gambar 1. Jumlah pengguna media social

(katadata, n.d.)

Gambar ini diambil dari hasil reset Waeresosial Hootsuite yang dirilis pada januari 2019. Pada gambar tersebut menunjukkan bahwa jumlah pengguna media social dinegara Indonesia mencapai serratus lima puluh (150) juta jiwa atau sejumlah lima puluh enam persen (56\%) dari total populasi. Sementara pengguna media social mobile (gadget) mencapai serratus tiga puluh (130) jiwa atau sekitar $48 \%$ dari populasi. Dari data tersebut dapat disimpulkan bahwa penggunaan media social oleh orang Indonesia tinggi, dari hasil penelitian We are social (perusahaan media inggris) ini juga ratarata orang Indonesia menghabiskan waktunya 3 jam 23 menit dalam sehari untuk menggunakan media social.terlebih lagi pemerintah akan membuat palapa ring yang ditargetkan selesai pada tahun ini, sehingga kemungkinan besar akan semakin meningkatkan penetrasi internet dan media social oleh orang Indonesia.

\section{B. Edukasi}

Edukasi adalah suatu proses pengajaran yang bertujuan untuk meningkatkan pengetahuan dan mengembangkan potensi diri bagi para peserta didik. Edukasi ini bertujuan untuk memberikan pemahaman kepada masyarakat tentang apa itu pemasyarakatan, apa itu hak asasi manusia, dan apa yang dilakukan pemasyarakatan untuk membela hak asasi manusia dari para tahanan, narapidana, dan mantan narapidana. (Kusniyati \& Pangondian Sitanggang, 2016) 


\section{Pemasyarakatan}

Dijelaskan di dalam Undang-Undang Nomor 12 Tahun 1995 tentang Pemasyarakatan, bahwa Sistem Pemasyarakatan adalah suatu aturan mengenai arah dan batas serta tata cara pembinaan Warga Binaan Pemasyarakatan agar menyadari kesalahan, memperbaiki diri, dan tidak mengulangi tindak pidana sehingga dia dapat diterima kembali oleh lingkungan masyarakat, dapat berperan aktif dalam pembangunan, dan dapat hidup secara wajar sebagai warga negara yang baik. Sedangkan lembaga pemasyarakatan yang selanjutnya disebut lapas adalah tempat untuk melaksanakan pembinaan narapidana dan anak didik pemasyarakatan. Maka dari itu petugas pemasyarakatan dituntut bukan hanya menerima pelaku tindak pidana saja namun juga bertanggung jawab atas kondisi baik fisik maupun psikilogis dari narapidana itu sendiri. Lembaga Pemasyarakatan yang selanjutnya disebut Lapas adalah tempat untuk melaksanakan pembinaan terhadap Narapidana dan Anak Didik Pemasyarakatan. Rumah Tahanan Negara yang selanjutnya disebut Rutan adalah tempat untuk proses pelayanan tahanan yang dilaksanakan mulai dari penerimaan sampai dengan pengeluaran tahanan.

Dalam melakukan penelitian ini, penulis melakukan metode wawancara kepada responden yaitu masyarakat yang latar belakang pendidikannya sd, smp, sma, strata 1 (S1), dan strata 2 (S2). Dari hasil wawancara yang dilakukan oleh peneliti, dapat disimpulkan bahwa masih banyak masyarakat yang belum tahu tentang apa itu pemasyarakatan. Dan juga masih belum samanya persepsi terhadap tujuan pemasyarakatan yaitu pembinaan, bukan malah penjeraan yang malah melanggar hak asasi dari tahanan dan narapidana itu sendiri.

\section{Permasalahan diLapas dan Rutan Indonesia}

\begin{tabular}{ccccc}
\hline No. & Kanwil & $\begin{array}{c}\text { Jumlah } \\
\text { penghuni }\end{array}$ & Kapasitas & \% Over Kapasitas \\
\hline $\mathbf{1}$ & Aceh & 8591 & 4090 & 110 \\
\hline $\mathbf{2}$ & Banten & 3586 & 1518 & 136 \\
\hline $\mathbf{3}$ & Bali & 2334 & 1348 & 73 \\
\hline $\mathbf{4}$ & Bangka Belitung & 11264 & 11264 & 94 \\
\hline $\mathbf{5}$ & Bengkulu & 2770 & 1632 & 70 \\
\hline $\mathbf{6}$ & Yogyakarta & 1597 & 2010 & 0 \\
\hline $\mathbf{7}$ & Jakarta & 18367 & 5791 & 217 \\
\hline $\mathbf{8}$ & Gorontalo & 997 & 888 & 12 \\
\hline $\mathbf{9}$ & Jambi & 4446 & 2256 & 97 \\
\hline $\mathbf{1 0}$ & Jawa barat & 23235 & 15808 & 47 \\
\hline
\end{tabular}




\begin{tabular}{|c|c|c|c|c|}
\hline 11 & Jawa tengah & 13875 & 9008 & 54 \\
\hline 12 & Jawa timur & 29437 & 12757 & 131 \\
\hline 13 & Kalimantan barat & 5453 & 2529 & 116 \\
\hline 14 & Kalimantan selatan & 9493 & 3467 & 174 \\
\hline 15 & Kalimantan tengah & 4423 & 2344 & 89 \\
\hline 16 & Kalimantan timur & 12666 & 3586 & 253 \\
\hline 17 & Kepulauan riau & 4677 & 2505 & 87 \\
\hline 18 & lampung & 9419 & 5348 & 76 \\
\hline 19 & Maluku & 1519 & 1365 & 11 \\
\hline 20 & Maluku utara & 1215 & 1477 & 0 \\
\hline 21 & Nusa tenggara barat & 2993 & 1269 & 136 \\
\hline 22 & $\begin{array}{c}\text { Nusa tenggara } \\
\text { timur }\end{array}$ & 3318 & 2870 & 16 \\
\hline 23 & papua & 2597 & 2267 & 15 \\
\hline 24 & Papua barat & 1025 & 1004 & 2 \\
\hline 25 & Riau & 12768 & 4170 & 206 \\
\hline 26 & Sulawesi barat & 870 & 1022 & 0 \\
\hline 27 & Sulawesi selatan & 11340 & 5843 & 94 \\
\hline 28 & Sulawesi tengah & 3493 & 1609 & 117 \\
\hline 29 & Sulawesi tenggara & 2790 & 2146 & 30 \\
\hline 30 & Sulawesi utara & 2745 & 2153 & 27 \\
\hline 31 & Sumatera barat & 5972 & 3217 & 86 \\
\hline 32 & Sumatera selatan & 14651 & 6605 & 122 \\
\hline 33 & Sumatera utara & 35128 & 12574 & 179 \\
\hline
\end{tabular}

Dari data tersebut, dapat kita lihat dan disimpulkan bahwa sebagian besar dilembaga pemasyarakatan atau yang lebih dikenal dengan sebutan Lapas, dan rumah tahanan negara atau biasa disebut dengan Rutan diseluruh Indonesia telah mengalami kelebihan penghuni, atau biasa dikenal dengan over kapasitas. Hal ini dikarenakan tingginya tingkat residivis dan perbedaan persepsi antar sub sistem peradilan pidana dan juga masyarakat luas yang masih beranggapan orang yang melanggar hukum atau melakukan tindak pidana harus dijerakan agar tidak mengulangi kesalahannya lagi. Dan juga narapidana yang telah selesai menjalani masa pidana tidak bisa mendapatkan pekerjaan karena citranya sudah dipandang buruk oleh masyarakat. Pandangan masyarakat ini adalah cara berfikir lama, yaitu pada saat masih menggunakan sistem kepenjaraan, sedangkan sekarang ini Indonesia telah menerapkan sistem pemasyarakatan sebagai pengganti sistem kepenjaraan itu sendiri. (Rusliyadi et al., 1995) 
Permasalahan kelebihan muatan atau yang biasa disebut dengan over kapasitas dilapas seluruh Indonesia adalah suatu permasalahan yang sudah terjadi sejak lama. Permasalahan ini bukan hanya dikarenakan oleh kurangnya pembangunan bangunan lapas diseluruh Indonesia, tapi juga harus dilihat dari sisi faktor lainnya yang menyebabkan permasalahan ini muncul. Perlu kita ketahui juga bahwa penuhnya lapas diIndonesia tidak hanya karena dihuni oleh Narapidana (orang yang sudah mendapatkan putusan pengadilan), tapi juga karena dihuni oleh tahanan (orang yang masih menunggu proses penuntutan). (Edy Susanto, 2019)

Berikut ini adalah faktor utama yang menyebabkan terjadinya over kapasitas didalam lapas menurut Edwin Yonatan sunarjo (Sunarjo, n.d.):

1. Faktor mudahnya seseorang ditahan ketika disangka atau didakwa melakukan tindak pidana.

Penahanan berdasarkan ketentuan umum dalam Kitab Undang-Undang Hukum Pidana (selanjutnya KUHP) adalah penempatan terdakwa atau tersangka ditempat tertentu oleh hakim, penyidik atau penuntut umum dengan penempatannya. (Utami, 2017) dalam Pasal 21 KUHAP, Penahanan dilakukan dengan tujuan yang telah diatur yaitu: tersangka atau terdakwa diduga akan melarikan diri, merusak atau menghilangkan barang bukti, atau mengulangi tindak pidana. Dan perlu diketahui bahwa penahanan adalah hal yang tidak wajib dilakukan, karena hakekatnya penahanan adalah pelanggaran terhadap hak asasi manusia. Selain itu, tidak semua tindak pidana dapat dilakukan penahanan terhadap tersangka ataupun terdakwa, tetapi hanya kepada tersangka atau terdakwa atas tindak pidana yang memiliki ancaman lebih dari 5 tahun atau melanggar pasal yang diatur dalam Pasal 21 ayat 4 butir $b$.

Akan tetapi, bila dilihat kondisi dilapangan, sebagian besar terdakwa dan tersangka akan ditahan, karena syarat dalam Pasal 21 ayat 1 tersebut dapat diartikan secara subjektif oleh instansi berwenang melakukan penahanan. Hal ini diperparah dengan syarat dalam Pasal 21 ayat 4 butir a banyak dilanggar, dimana tersangka dan terdakwa yang masa hukumannya 5 tahun juga tetap ditahan. Penahanan yang merupakan pelanggaran HAM malah dianggap sebagai kebiasaan dan membudaya, jadi tidak heran jika jumlah tahanan terus meningkat, yang mengakibatkan pada banyaknya tahanan yang mengisi Rumah Tahanan Negara (RUTAN) dan mengakibatkan over kapasitas. (Marzuki, 2015)

2. SOP penangguhan penahanan yang masih belum jelas. 
Setiap penahanan yang dilakukan oleh pejabat yang berwenang, juga terlekat hak dari tersangka atau terdakwa untuk mengajukan penangguhan penahanan. Penangguhan penahanan merupakan pengeluaran tersangka atau terdakwa dari penahanan sebelum batas waktu penahanannya berakhir. Hal ini juga sudah diatur oleh KUHAP dalam Pasal 31, tapi yang jadi permasalahan adalah tidak adanya ketentuan yang mengatur mengenai alasan yang dapat dibenarkan untuk dikabulkannya penangguhan penahanan sehingga semuanya berdasarkan subjektifitas pejabat yang berwenang. (Objektifitas, Subjektifitas, \& Penahanan, 2019)

3. Kurang maksimalnya penggunaan jenis pemidanaan lain selain penjara.

Didalam KUHP sebenarnya dijelaskan bahwa ada 5 jenis pidana pokok, yaitu:pidana mati, pidana penjara, pidana kurungan, denda, dan tutupan. Akan tetapi kenyataannya putusan pidana lebih sering dijatuhkan sehingga menyebabkan pidana pokok lain sering terlupakan. (Rumadan, 2013)

4. Tingkat residivis yang masih tinggi

Seorang pelaku tindak pidana yang telah bebas dari masa hukumannya, kemudian dia malah melakukan tindak pidana lagi, maka itu adalah residivis. Seorang yang melakukan tindak pidana kembali bisa terjadi karena banyak hal, salah satunya adalah ketika dia telah selesai menjalani masa pidananya dan akan kembali kedalam masyarakat, akan tetapi masyarakat menstigma buruk dan tidak menerima keberadaan simantan pelaku tindak pidana ini. Akhirnya mantan pelaku tindak pidana ini tidak dapat menerapkan hasil pembinaan dilapas, hingga mendorong dia untuk melakukan tindak pidana lagi. (Yusuf \& Patrisia, 2011)

\section{E. Pelanggaran HAM terhadap tahanan dan narapidana}

Dari permasalahan over kapasitas lapas dan rutan diatas bahwa terjadinya pelanggaran HAM yang terjadi kepada tahanan dan narapidana dalam lapas dan rutan di Indonesia. Para tahanan dan narapidana yang masuk kedalam lapas dan rutan diharuskan menanggung beban dua kali yaitu terbebani dengan beban hukuman pidana yang dijatuhkan kepadanya, dan juga beban tidak dimanusiakannya para tahanan dan narapidana karena harus hidup didalam ruangan yang isinya melebihi kapasitas. Padahal dalam undang-undang dasar Republik Indonesia tahun 1945 pasal 28H ayat (1) dijelaskan bahwa "setiap orang 
berhak hidup sejahtera lahir dan batin, bertempat tinggal dan mendapatkan lingkungan hidup yang baik dan sehat serta berhak memperoleh pelayanan kesehatan."

Dan apabila dilihat dari faktor - faktor penyebab permasaslahan over kapasitas lapas dan rutan di Indonesia karena tidak perdulinya masyarakat terhadap hak-hak asasi yang dimiliki oleh tahanan dan narapidana. Sebagai contoh pada saat seseorang menjalani masa penahanan, masyarakat ingin orang tersebut dihukum yang seberat-beratnya agar tahanan tersebut mendapatkan efek jera, bahkan ada yang berpendapat bahwa orang yang melakukan tindak pidana korupsi dibinasakan saja. padahal didalam pasal 28 i ayat (1) dijelaskan bahwa seseorang berhak untuk hidu, berhak untuk tidak disiksa, berhak untuk kemerdekaan pikiran dan hati nurani, hak beragama, hak untuk tidak diperbudak, hak untuk diakui sebagai pribadi dihadapan hukum, dan hak untuk tidak dituntut atas dasar hukum yang berlaku surut, itu adalah hak asasi manusia yang tidak dapat dikurangi dalam keadaan apapun.

Contoh lain seperti pada saat mantan narapidana sudah selesai menjalani masa pidananya dan ingin menjalani kehidupannya kembali kedalam masyarakat, sebagai orang normal kembali, malah mendapatkan sikap diskriminatif berupa stigma buruk terhadap mantan narapidana tersebut, menyebabkan narapidana tersebut tidak bisa mendapatkan pekerjaan hingga melakukan kejahatan kembali (residivisme). Padahal didalam pasal 28 I ayat (2) dijelaskan bahwa setiap orang bebas dari perlakuan diskriminatif atas dasar apapun dan berhak mendapatkan perlindungan terhadap perlakuan yang bersifat diskriminatif.

Dijelaskan dalam pasal 28 i ayat (4) bahwa perlindungan, pemajuan penegakkan, dan pemenuhan hak asasi manusia adalah tanggung jawab negara, terutama pemerintah. Maka dari itu, pemerintah harus ada langkah kongkrit yang dilakukan oleh pemerintah untuk pemenuhan HAM tahanan dan narapidana dengan cara mengedukasi masyarakat dan para stakeholder pemasyarakatan lainnya.

\section{F. Edukasi Sistem Pemasyarakatan dengan menggunakan media massa}

Menurut Satjipto Rahardjo, teori Perlindungan hukum adalah memberikan pengayoman terhadap hak asasi manusia (HAM) yang dirugikan orang lain dan perlindungan itu diberikan kepada masyarakat agar menikmati semua hak-hak yang diberikan oleh hukum. berbeda dengan keadaan yang terjadi, masyarakat malah tidak memberikan pengayoman kepada mantan narapidana. (Sudrajat, 2011) 
Dari filosofi pemasyarakatan, sistem pemasyarakatan memiliki asumsi bahwa manusia (termasuk juga narapidana) adalah mahluk sosial yang secara harfiah memiliki kebutuhan untuk selalu berhubungan dengan masyarakat, dan terutama dengan keluarganya. Disamping itu, paradigma pemasyarakatan menganggap bahwa seseorang melanggar hukum itu diakibatkan karena ketidak harmonisan antara dirinya dengan :

1. Tuhannya (aspek hidupnya)

2. Masyarakatnya (aspek kehidupannya)

3. Dan lingkungan atau pekerjaannya (aspek penghidupannya). (Pemasyarakatan \& Sulhin, 2010)

Maka dari itu orang yang melanggar hukum atau yang akrab dikenal dengan dengan sebutan narapidana tidak boleh dijauhkan dari keluarga ataupun masyarakat. Dengan demikian, pembinaannyapun harus mengarahkan kepada pemulihan hubungan dengan salah satu atau ketiga aspek tersebut. Salah satunya adalah dengan cara melaksanakan pemulihan hubungan dengan masyarakat dengan cara pelaksanaan proses pembinaan secara bertahap yang dimulai dengan proses program pembebasan bersyarat, cuti mengunjungi keluarga, cuti menjelang bebas, dll.

Menurut Freeman, 1984:25, stakeholder adalah sebuah kelompok atau individu yang dapat mempengaruhi atau dipengaruhi untuk mencapai tujuan sebuah organisasi (Pratama, 2018) Dari teori tersebut, artinya tujuan dari pemasyarakatan akan tercapai apabila stakeholdernya mendukung tujuan dari pemasarakatan. Untuk stakeholder pemasyarakatan sendiri adalah aparat penegak hukum dan masyarakat, maka perlu adanya peran dari pemerintah (apparat penegak hukum) dan masyarakat dalam merealisasikan tujuan dari pemasyarakatan.

Dari data sebelumnya, mayoritas masyarakat Indonesia menggunakan internet dan media social dalam kesehariannya. Hal ini menyatakan bahwa pada era globalisasi ini, penggunaan internet menjadi suatu kebutuhan bagi masyarakat Indonesia. Bagi para pembisnis, internet bisa dijadikan alat untuk melakukan promosi bagi produk yang akan mereka jual. Berbeda dengan pemerintah atau Aparatur Sipil Negara (ASN) ,Melalui media massa ini, pemerintah dapat menyebarluaskan kepada masyarakat tentang informasi yang ingin disampaikan. Mungkin memang pemerintah sudah melakukan beberapa cara untuk mengedukasi dan mensosialisasikan sistem pemasyarakatan kemasyarakat, contohnya saja seperti membuat acara seminar kemahasiswa dan siswa sekolah, atau dengan cara membuat tulisan-tulisan ilmiah tentang 
pemasyarakatan. akan tetapi, dengan cara itu saja tidaklah cukup, karena yang akan menjadi audiens hanyalah orang-orang yang menjadi audiens atau orang-orang yang membaca tulisan ilmiah tersebut.

Dengan media massa, kementerian hukum dan ham yang khususnya direktorat jenderal pemasyarakatan dapat bekerja sama dengan kementerian komunikasi dan informasi untuk menyebarluaskan informasi kepada masyarakat berupa pemahaman tentang pemasyarakatan. (Sasetyo, 2012) Hal ini bertujuan untuk mengubah persepsi masyarakat terhadap narapida, dan pandangan masyarakat terhadap tersangka pelaku pidana. Karena pada hakekatnya, tersangka dan narapidana juga manusia yang juga harus diperjuangkan hak asasi manusianya. Hal yang perlu dilakukan adalah membuat suatu iklan atau pesan singkat tentang pemasyarakatan. Berikut langkah - langkah yang harus dilakukan oleh pemerintah :

1. Bekerja sama dengan Kemenkominfo untuk membuat iklan tentang pemasyarakatan dan menyebarluaskannya.

2. Memasukkan unsur-unsur pemasyarakatan keberbagai film di Indonesia

3. Membuat Film pendek (short movie) tentang narapidana yang mendapatkan stigma buruk dari masyarakat.

4. mengiklankan pemasyarakatan ditelevisi dan diberbagai media sosial.

5. Untuk iklan dimedia sosial, dimunculkan pada saat orang sedang melakukan aktivitas dengan gadgetnya, serta tidak ada skip atau melewati iklan tersebut agar orang membaca/melihat pesan tersebut.

Metode untuk mengirimkan iklan atau pesan singkat ini bisa dengan menggunakan berbagai cara. berikut ini adalah berbagai cara yang dapat digunakan pemerintah untuk menyebarluaskan iklan atau pesan singkat tersebut dengan cara meniru gaya promosi pembisnis (winstarlink, n.d.) :

1. Viral Information

Viral promotion adalah cara menyebarluaskan pesan singkat dengan meniru promosi dari mulut kemulut tapi menggunakan media internet. Promosi itu dilakukan dengan menempelkan iklan teks yang sering juga berisi link kesitus/katalog pada setiap e-mail yang dikirim kemasyarakat, bahkan ada juga yang menempelkannya pada software atau artikel atau publikasi lain yang dapat didownload. (Situmorang, 2010)

2. E-mail Publishing 
adalah cara mengiklankan pemasyarakatan dengan mengirimkan iklan, pesan singkat, ataupun artikel tentang perubahan paradigma dari penjara kepemasyarakatan melalui media e-mail kemasyarakat.

\section{Networking}

Adalah cara untuk mensosialisasikan pemasyarakatan kemasyarakat dan penegak hukum dengan cara pembuatan mailing list atau discussion group. (Afdjani Hadiono, 2010)

\section{G. Manfaat penggunaan media massa untuk mensosialisasikan pemasyarakatan}

Berikut adalah manfaat apabila Kementerian Hukum dan Ham mensosialisasikan pemasyarakatan dengan menggunakan media massa, yaitu :

1. Jangkauannya lebih luas untuk mengedukasi masyarakat, karena menggunakan media massa.

2. Karena masyarakat Indonesia cenderung menggunakan media massa dalam kesehariannya, maka pesan yang disampaikan akan mudah tersampaikan.

3. Tidak seperti cara mengedukasi konvensional, orang yang menerima pesan ini, bukan hanya audiens atau siswa sekolah saja. Tapi juga masyarakat lainnya karena menggunakan media massa.

4. Mengubah citra tahanan dan narapidana yang telah selesai menjalani masa pidananya. Karena setelah pemasyarakatan dipublikasikan kemasyarakat, maka masyarakat akan tau dan mengubah pemikirannya terhadap tahanan dan narapidana tersebut, bahwa tahanan dan narapidana juga manusia yang memiliki HAM yang harus dijunjung tinggi oleh masyarakat.

\section{KESIMPULAN}

Sebagian besar masyarakat yang masih belum memahami tugas dan fungsi serta tujuan dari pemasyarakatan, mengakibatkan terjadinya stigma buruk dari masyarakat baik terhadap tahanan yang statusnya masih tersangka atau terdakwa maupun mantan narapidana yang sudah berintegerasi kembali ke dalam masyarakat. Untuk mengatasi permasalahan ini, pemerintah khususnya petugas pemasyarakatan dapat mengedukasi masyarakat tentang pemasyarakatan, dan hak asasi tahanan-mantan narapidana dengan menggunakan media massa.

Hal yang perlu diperhatikan pemerintah dalam mensosialisasikan pemasyarakatan melalui media internet/media sosial ini adalah memperhatikan karakteristik masyarakat. Biasanya masyarakat akan dengan mudah mencerna informasi yang didapat apabila informasi tersebut disajikan dengan gambar. Biasanya, satu gambar akan berbicara banyak, dan masyarakat akan tertarik dengan 
informasi yang disajikan dengan gambar. Selain itu dalam menggunakan media massa berupa sosial media, pemerintah juga bisa membuat iklan/pesan singkat yang dapat dimunculkan pada tempat-tempat umum seperti bioskop, restoran, tempat wisata, dan lain - lain.

\section{REFERENSI}

Afdjani Hadiono. (2010). ( Studi Fenomenologi Pemirsa Di Jakarta Terhadap Iklan Televisi Minuman “Kuk U Bima Energi ” Versi Kolam Susu ). Jurnal Ilmu Komunikasi, 8(April), 14.

Akmala, N. (2020). kasus yang menyayat hati. Retrieved from https://www.brilio.net/duh/5kasus-hukum-paling-menyayat-hati-ada-nenek-92-tahun-divonis-penjara-1802028.html

Bachri, B. S. (2010). Meyakinkan Validitas Data Melalui Triangulasi Pada Penelitian Kualitatif. Teknologi Pendidikan, 10, 46-62.

Ditjenpas. (2020). jumlah penghuni Lapas/Rutan. Retrieved from http://smslap.ditjenpas.go.id/public/grl/current/monthly

Edy Susanto, M. (2019). Analisis Resiko Keuagan. Journal of Chemical Information and Modeling, 53(9), 1689-1699. https://doi.org/10.1017/CBO9781107415324.004

Ghufron, M. A. (2018). Revolusi industri 4.0: Tantangan, Peluang dan Solusi Bagi Dunia Pendidikan. Seminar Nasional Dan Diskusi Panel Multidisiplin Hasil Penelitian Dan Pengabdian Kepada Masyarakat, 332-337.

Husaini dan Lampung. (2014). Pemanfaatan Teknologi Informasi Dalam Bidang Pendidikan (E-Education). Jurnal Mikrotik, 2(1), 1-5.

katadata. (n.d.). data Pengguna media. Retrieved February 25, 2020, from https://databoks.katadata.co.id/datapublish/2019/02/08/berapa-pengguna-media-sosialindonesia

Komunikasi, P. (n.d.). Pengertian media sosial menurut Para ahli. Retrieved February 25, 2020, from https://pakarkomunikasi.com/pengertian-media-sosial-menurut-para-ahli

Kusniyati, H., \& Pangondian Sitanggang, N. S. (2016). Aplikasi Edukasi Budaya Toba Samosir Berbasis Android. Jurnal Teknik Informatika, 9(1), 9-18. https://doi.org/10.15408/jti.v9i1.5573

Marzuki, S. (2015). Pengadilan Yang Fair: Kecenderungan Pelanggaran Kode Etik Dan Pedoman Perilaku Oleh Hakim. Jurnal Hukum Ius Quia Iustum, 22(3), 394-419. https://doi.org/10.20885/iustum.vol22.iss3.art4

Messaile, H. (2015). Refleksi 50 tahun Sistem pemasyarakatan anatomi permasalahan dan upaya mengatasinya.

Muslich, M. (n.d.). jenis-jenis media massa. Retrieved from http://sastra.um.ac.id/wpcontent/uploads/2009/10/Kekuasaan-Media-Massa-Mengontruksi-Realitas-MasnurMuslich.pdf

Nola, L. F. (2016). Upaya Pelindungan Hukum Secara Terpadu Bagi Tenaga Kerja Indonesia (Tki). Negara Hukum, 7, 1-16. 
Objektifitas, S., Subjektifitas, D. A. N., \& Penahanan, P. (2019). De lega lata, 4, 175-188.

Pratama, R. (2018). Analisis Pemetaan Jejaring Stakeholder Pariwisata di kota Batu Dengan Menggunakan Metode Social Network Analysis (SNA). Jurnal Administrasi Bisnis (JAB), 54(1), 179-188.

Rumadan, I. (2013). Problem Lembaga Pemasyarakatan Di Indonesia Dan Reorientasi Tujuan Pemidanaan. Jurnal Hukum Dan Peradilan, 2(2), 263. https://doi.org/10.25216/jhp.2.2.2013.263-276

Santosa, B. A. (2017). Peran media massa dalam mencegah konflik. Jurnal Aspikom, 3(2), 199214.

Sasetyo. (2012). Pengaruh Daya Tarik Iklan Terhadap Pembentukan Citra Merek Pepsodent. Students E-Journal, $1(1), \quad 24 . \quad$ Retrieved from http://jurnal.unpad.ac.id/ejournal/article/view/1527

Situmorang, J. R. (2010). Pemasaran Viral - Viral Marketing. Jurnal Administrasi Bisnis Unpar, 6(1), 63-75.

Sudrajat, T. (2011). Perlindungan Hukum terhadap Hak Anak sebagai Hak Asasi Manusia. Jurnal.Unsyiah.Ac.Id/Kanun, (54), 111-132. Retrieved from http://www.jurnal.unsyiah.ac.id/kanun/article/view/6245/5150

Sunarjo, E. Y. (n.d.). permasalahan dilapas. Retrieved from http://leip.or.id/permasalahanpenyebab-kelebihan-jumlah-narapidana-di-lembaga-pemasyarakatan/

Suwardana, H. (2018). Revolusi Industri 4. 0 Berbasis Revolusi Mental. JATI UNIK : Jurnal $\begin{array}{lllll}\text { Ilmiah Teknik Dan Manajemen } & 102 .\end{array}$ https://doi.org/10.30737/jatiunik.v1i2.117

Utami, P. N. (2017). Keadilan Bagi Narapidana di Lembaga Pemasyarakatan. Jurnal Penelitian Hukum De Jure, 17(3), 381. https://doi.org/10.30641/dejure.2017.v17.381-394

Victorio H.Situmorang. (2019). Lembaga pemasyrakatan sebagai bagian dari penegakan hukum (Correctional Institution as Part of Law Enforcement). Jurnal Ilmiah Kebijakan Hukum, 13(1), 85-98.

Yusuf, U., \& Patrisia, R. (2011). Pengaruh Terapi Kognitif Perilaku Terhadap Peningkatan Kontrol Diri Pada Residivis. Jurnal Intervensi Psikologi (JIP), 3(2), 245-256. https://doi.org/10.20885/intervensipsikologi.vol3.iss2.art6 